\section{Kidney Blood Pressure Research}

Original Paper

\title{
Impact of Vitamin D Receptor VDR rs2228570 Polymorphism in Oldest Old
}

\author{
Melanie Glocke Florian Lang $^{\mathrm{a}} \quad$ Elke Schaeffeler $^{\mathrm{b}} \quad$ Thomas Lang $^{\mathrm{b}}$ \\ Matthias Schwabb ${ }^{b, c}$ Undine E. Lang ${ }^{d}$
}

aDepartment of Physiology, University of Tuebingen, Germany; ${ }^{b}$ Dr Margarete-Fischer-Bosch-Institute of Clinical Pharmacology, Stuttgart, Germany; 'Department Clinical Pharmacology, University Hospital

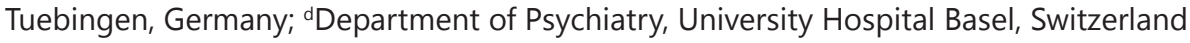

\section{Key Words}

Ageing • Gene variant $•$ Vitamin D $\cdot$ Calcitriol - Osteoporosis - Transitoric ischemic attacks • Hypertension • Allergy • Depression

\begin{abstract}
Background: Calcitriol, a key player in the regulation of mineral metabolism, influences, directly or by increasing plasma $\mathrm{Ca}^{2+}$ and phosphate levels, a multitude of physiological functions, such as bone mineralization, cell proliferation, immune response, carbohydrate metabolism, blood pressure, platelet reactivity, gastric acid secretion, cognitive function and mood. Calcitriol is mainly effective by stimulation of the Vitamin D receptor VDR. The responsiveness of VDR may be affected by gene variants, such as the FokI polymorphism (rs2228570). The GG gene variant is expected to be more active than the GA or AA gene variant. The present study explored the impact of VDR rs2228570 on survival and health of oldest old individuals (> 90 years). Methods: 101 individuals $>90$ years were examined and genotyped. As a result, the prevalence of GG, GA \& AA was $36(10 \hat{\partial}, 26$ ㅇ $), 52(24 \lambda, 28$ ) $)$ and $13(4 \hat{\jmath}, 9$ +), respectively, a prevalence not significantly different from the frequency in public available dbSNP and a population ( $n=208$ ) of young volunteers (average age 49 years). Results: As compared to carriers of GG, carriers of AA and/or GA displayed significantly $(p<0.05)$ lower diastolic blood pressure (significant only in $\delta^{\Uparrow}$ ), higher instrumental activity of daily life (IADL)

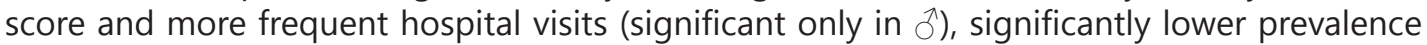
of depression (significant in $q+{ }^{\lambda}$ ), renal disease (significant only in $q$ ), allergy, peptic ulcer and urolithiasis (significant only in ${ }^{\lambda}$ ), as well as significantly higher prevalence of transitoric ischemic attacks. In a younger population a German version of the NEO-FFI, allowing reliable and valid assessment of personality, revealed decreased neuroticism (significant only in ${ }^{\lambda}$ ) and increased extraversion in AA carriers. Conclusion: The Vitamin D receptor gene variant VDR rs2228570 has only little impact on life span but may affect a variety of pathophysiologically relevant functions including mood.
\end{abstract}




\section{Kidney Blood Pressure Research}

\section{Introduction}

Physiologically active 1,25 -dihydroxyvitamin $\mathrm{D}\left(1,25(\mathrm{OH})_{2} \mathrm{D}_{3}\right)$ [1], is produced in kidney [2], B cells [3] as well as activated DCs and macrophages [4, 5]. The hormone is a powerful regulator of cellular and systemic $\mathrm{Ca}^{2+}$ and phosphate metabolism as well as bone mineralization [1]. Moreover, $1,25(\mathrm{OH})_{2} \mathrm{D}_{3}$ is a potent regulator of the immune response [68], of glucose metabolism [9], and of behavior [10,11]. Vitamin D deficiency thus predisposes not only to osteomalacia [12], but as well to diseases seemingly unrelated to $\mathrm{Ca}^{2+}$ phosphate metabolism including diabetes mellitus, hypertension, infections, asthma and cancer (for review see $[13,14]$ ) as well as several psychiatric disorders, such as depression, bipolar disorder and schizophrenia [15-17]. Vitamin D intake may counteract multiple sclerosis [18] and fibromyalgia [19]. Vitamin D receptor (VDR) and metabolizing enzymes are expressed in a wide variety of tissues $[20,21]$ including prefrontal cortex, hippocampus, cingulate gyrus, thalamus, hypothalamus, and substantia nigra of the brain [22].

Polymorphisms of VDR have been reported to be associated with bone mineral density [23] diabetes mellitus [24, 25], hypertension [26], asthma [27, 28], periodontitis [29, 30], risk of multiple sclerosis [31,32] and malignancy [33-38]. On the other hand, several studies failed to report an impact of VDR polymorphisms on multiple sclerosis [39], inflammatory bowel disease [40], coronary artery disease [41] or malignancy [42-44].

The present study explored, whether the FokI VDR polymorphism (rs2228570) impacts on life span and on health history of an elderly population (age $>90$ years). The A variant (f allele) of the FokI restriction fragment polymorphism [45] results in the generation of a longer VDR protein [46] with less activity [47]. The G (or guanosine) variant (F allele) is 1.7fold more active [48-50]. Carriers of the GG VDR gene variant are thus expected to have more VDR activity than carriers of the GA or AA gene variant. To date, the Fok1 polymorphism is the only known $V D R$ gene polymorphism that results in the generation of an altered protein [45].

\section{Materials and Methods}

A total of 101 volunteers $(38 \hat{\jmath}, 63$ ) ) with an age over 90 years were recruited, all of whom were unrelated individuals of German descent (Caucasians). For comparison, a group of 208 volunteers younger than 90 years $(123 \hat{\delta}, 85$ ) $)$ were included. Those individuals previously participated in a study on tinnitus [51]. No association was found between tinnitus and the polymorphism and the distribution of the polymorphism was similar in this population and the oldest old. The younger population completed the German version of the NEO-FFI [52], which consists of 60 items and allows reliable and valid assessment of personality along the dimensions neuroticism, extraversion, openness to experiences, agreeableness and conscientiousness [53]. The study was approved by the local ethics committee. After detailed information about the study, written informed consent was obtained by all study participants.

The study explored the occurrence of the FokI polymorphism (rs2228570) and its association with physical exams like body weight and blood pressure as well as selected disease entities reported by a faceto-face interview based on history data.

Leukocyte DNA was isolated using standard procedures (QIAamp DNA Blood Mini Kit, Qiagen, Hilden, Germany). Genotyping for rs2228570 was performed by a 5'nuclease assay using the predesigned TaqMan assay (Assay ID: C_12060045_20). Detection was performed by the ABI Prism 7900 Sequence Detection System (Applied Biosystems, Foster City, CA). Laboratory staff was blinded to the case status of the study participants during the entire genotyping process.

Data are provided as means \pm SEM. Data were analyzed by parametric or nonparametric methods, depending on whether data distribution was normal or not. For statistical analysis, the Student's t-test, the 


\section{Kidney Blood Pressure Research}

Table 1. Prevalence of Fok1-Polymorphisms. Numbers or percentages of individuals carrying the polymorphism in the group with age $>90$ (>90), the group of individuals with

\begin{tabular}{lcccccc}
\hline $\begin{array}{l}\text { Fok1 Polymorphism } \\
\text { (rs2228570) }\end{array}$ & \multicolumn{2}{l}{ Oldest old $(>90$ yrs $)$} & \multicolumn{2}{c}{ Controls $(<90$ yrs $)$} & HapMap-CEU* \\
\hline $\begin{array}{l}\text { Total number of } \\
\text { individuals }\end{array}$ & 101 & $\%$ & 208 & $\%$ & 113 & $\%$ \\
G allele frequency & 124 & 61.4 & 252 & 60.6 & 58.8 \\
A allele frequency & 78 & 38.6 & 164 & 39.4 & 41.2 \\
GG frequency & 36 & 35.6 & 75 & 36.1 & 37.2 \\
AA frequency & 13 & 12.9 & 31 & 14.9 & 19.5 \\
GA frequency & 52 & 51.5 & 102 & 49.0 & 43.4 \\
\hline
\end{tabular}

*Data derived from the public available dbSNP for subjects only with European origin (http://www.ncbi.nlm.nih.gov/projects/SNP/snp_ref.cgi?rs=2228570)

age $<90(<90)$ normal individual group and in common population (per dbSNP = Single Nucleotide Polymorphism database; $\mathrm{CEPH}-\mathrm{Col}=$ Centre d'Étude du Polymorphisme Humain-Collection; HapMap = haplotype map; $\mathrm{CEU}=\mathrm{Utah}$ residents with ancestry from northern and western Europe)

$\chi^{2}$-Test and the Mann-Whitney U-test were used as appropriate. All statistical tests were used two-tailed and a $p$-value of $\leq 0.05$ was defined as statistically significant. For all calculations the JMP IN software package version 5.1.2 was used (SAS institute Inc., Cary, NC, USA). A $p$ value of $p<0.05$ was considered significant. Correction for multiple testing was not performed since our study was explorative and not confirmatory.

\section{Results}

To explore the impact of the FokI polymorphism (rs2228570) on life span, the prevalence of the polymorphism in the elderly population (mean age 92) was compared to the prevalence in individuals younger than 90 years (mean age 49 years) and to the prevalence in the publicly available databases per dbSNP (Single Nucleotide Polymorphism database), CEPH$\mathrm{Col}=$ Centre d'Étude du Polymorphisme Humain-Collection) HapMap (haplotype map) and CEU (Utah residents with ancestry from northern and western Europe) (http://www.ncbi. nlm.nih.gov/projects/SNP/snp_ref.cgi?rs=2228570). As listed in table 1, in the oldest old population the prevalence of the GG genotype $\left(100^{\lambda}, 26\right.$ ) $)$ was higher than the prevalence of

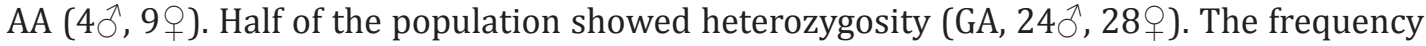
of genotypes was in Hardy-Weinberg equilibrium. A similar distribution of genotypes was found in the control group (GG 36.1\%, AA 14.9\% and GA 49.0\%) which was not significantly different to the frequency distribution of the public available HapMap-CEU cohort (GG: 37.2 $\%$; AA: $19.5 \%$ and GA: $43.4 \%$, table 1). The distribution of the rs 2228570 polymorphism was similar in all three cohorts, if males and females were grouped together. The percentage of males tended to be lower in oldest old carriers of either AA and GG than in heterozygote individuals, a difference significant $(p<0.05)$ for the GG carriers.

Additionally physical exam for selected parameters like blood pressure and well established geriatric assessment scores (i.e. Mini-Mental State Examination [MMSE], Instrumental Activities of Daily Living scale (IADL) were performed as listed in table 2. Blood pressure tended to be lower in the AA carriers and GA carriers than in GG carriers, a difference, however, reaching statistical significance only for diastolic blood pressure in male AA carriers. The prevalence of hypertension tended again to be lower in the AA carriers and GA carriers than in the GG carriers, a difference, however, not reaching statistical significance.

No significant differences between male or female genotypes were observed for size and body mass index (table 2). If both, female and male individuals were grouped together, body weight was significantly higher in GA- and GA\&AA carriers than in GG carriers, a difference at least in part due to the higher percentage of males in the GA- and GA\&AA carriers. Moreover, the MMSE-Score yielded similar mean values in all three groups. AG- and AA\&AG carriers 


\section{Kidney Blood Pressure Research}

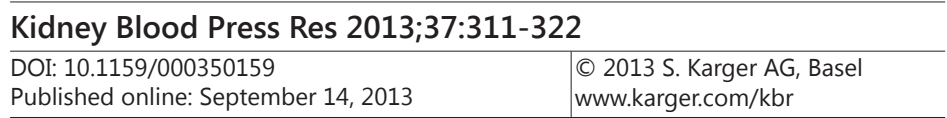

Table 2. Association between measured variables (MMSE = Mini-Mental-State Examination; IADL = Instrumental activity of daily life) in oldest old ( $>90$ years) and the VDR rs2228570 polymorphism

\begin{tabular}{|c|c|c|c|c|}
\hline $\begin{array}{l}\text { Genotype } \\
\text { (VDR rs2228570) }\end{array}$ & GG & AA & GA \& AA & GA \\
\hline Number & $36\left(26+100^{\lambda}\right)$ & $13\left(9+4{ }^{\lambda}\right)$ & $65\left(37+, 28 \delta^{\lambda}\right)$ & $52(28+, 24)$ \\
\hline Age & $93.44 \pm 0.62$ & $91.69 \pm 0.64$ & $92.43 \pm 0.31$ & $92.62 \pm 0.35$ \\
\hline q & $93.81 \pm 0.81$ & $92.33 \pm 0.85$ & $92.73 \pm 0.42$ & $92.86 \pm 0.48$ \\
\hline$\hat{\sigma}$ & $92.50 \pm 0.73$ & $90.25 \pm 0.25$ & $92.04 \pm 0.45$ & $92.33 \pm 0.50$ \\
\hline Size & $164.23 \pm 1.34$ & $168.09 \pm 2.79$ & $166.81 \pm 1.16$ & $166.50 \pm 1.28$ \\
\hline 우 & $161.36 \pm 1.21$ & $164.57 \pm 2.42$ & $161.16 \pm 1.08$ & $160.16 \pm 1.16$ \\
\hline o & $172.13 \pm 1.94$ & $174.25 \pm 5.57$ & $174.04 \pm 1.15$ & $174.00 \pm 1.00$ \\
\hline Weight kg & $60.48 \pm 2.07$ & $64.10 \pm 2.52$ & $65.70 \pm 1.36^{*}$ & $66.04 \pm 1.57^{*}$ \\
\hline 우 & $57.23 \pm 2.07$ & $60.00 \pm 2.68$ & $59.97 \pm 1.39$ & $59.96 \pm 1.63$ \\
\hline$\hat{\sigma}$ & $68.44 \pm 4.08$ & $70.25 \pm 2.95$ & $72.80 \pm 1.65$ & $73.29 \pm 1.89$ \\
\hline systolic blood pressure & $161.50 \pm 4.44$ & $152.69 \pm 6.26$ & $153.98 \pm 3.48$ & $154.31 \pm 4.09$ \\
\hline q & $162.65 \pm 5.49$ & $160.00 \pm 7.18$ & $159.81 \pm 4.71$ & $159.75 \pm 5.84$ \\
\hline 0 & $158.50 \pm 7.55$ & $136.25 \pm 8.39$ & $146.29 \pm 4.89$ & $147.96 \pm 5.52$ \\
\hline diastolic blood pressure & $85.03 \pm 1.92$ & $80.38 \pm 3.69$ & $79.97 \pm 1.69$ & $79.87 \pm 1.92$ \\
\hline 우 & $85.85 \pm 2.39$ & $85.00 \pm 4.48$ & $83.51 \pm 2.23$ & $83.04 \pm 2.62$ \\
\hline$\hat{\sigma}$ & $82.90 \pm 3.10$ & $70.00 \pm 2.12 *$ & $75.29 \pm 2.35$ & $76.17 \pm 2.69$ \\
\hline Blood pressure amplitude & $76.47 \pm 3.66$ & $72.31 \pm 3.77$ & $74.02 \pm 2.93$ & $74.44 \pm 3.55$ \\
\hline 우 & $76.81 \pm 4.56$ & $75.00 \pm 4.33$ & $76.30 \pm 4.05$ & $76.71 \pm 5.21$ \\
\hline$\hat{\sigma}$ & $75.60 \pm 6.07$ & $66.25 \pm 7.38$ & $71.00 \pm 4.20$ & $71.79 \pm 4.77$ \\
\hline Body mass index & $22.42 \pm 0.75$ & $22.64 \pm 0.60$ & $23.58 \pm 0.42$ & $23.79 \pm 0.50$ \\
\hline \multirow[t]{2}{*}{ q } & $22.03 \pm 0.81$ & $22.27 \pm 0.86$ & $23.18 \pm 0.62$ & $23.40 \pm 0.74$ \\
\hline & $23.49 \pm 1.74$ & $23.19 \pm 0.83$ & $24.07 \pm 0.57$ & $24.24 \pm 0.66$ \\
\hline MMSE score & $27.14 \pm 0.93$ & $28.38 \pm 0.56$ & $27.95 \pm 0.31$ & $27.84 \pm 0.37$ \\
\hline 우임 & $27.00 \pm 1.21$ & $27.89 \pm 0.73$ & $27.57 \pm 0.44$ & $27.46 \pm 0.53$ \\
\hline$\sigma^{*}$ & $27.50 \pm 1.34$ & $29.50 \pm 0.50$ & $28.50 \pm 0.42$ & $28.32 \pm 0.49$ \\
\hline IADL-score & $5.56 \pm 0.44$ & $6.69 \pm 0.56$ & $6.66 \pm 0.24^{*}$ & $6.65 \pm 0.27^{*}$ \\
\hline 우 & $5.50 \pm 0.50$ & $6.67 \pm 0.65$ & $6.38 \pm 0.32$ & $6.29 \pm 0.37$ \\
\hline 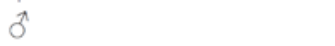 & $5.70 \pm 0.94$ & $6.75 \pm 1.25$ & $7.04 \pm 0.36$ & $7.08 \pm 0.38$ \\
\hline Hospital visits & $4.34 \pm 0.84$ & $4.15 \pm 0.72$ & $4.43 \pm 0.36$ & $4.50 \pm 0.42$ \\
\hline 우 & $4.40 \pm 1.16$ & $2.89 \pm 0.61$ & $3.51 \pm 0.34$ & $3.71 \pm 0.41$ \\
\hline$\hat{0}$ & $4.20 \pm 0.59$ & $7.00 \pm 0.82 *$ & $5.64 \pm 0.64$ & $5.42 \pm 0.73$ \\
\hline
\end{tabular}

did, however, score significantly higher than GG carriers in IADL-score. The frequency of hospital visits was significantly higher in male AA carriers than in GG carriers, but tended to be lower in female AA carriers than in female GG carriers. Taken together, the frequency of hospital visits was not significantly different between GG carriers and AA carriers. No significant differences between GG carriers and the other genotypes (AA carriers, GA carriers or GA\&AA) was observed in the prevalences of osteoporosis, myocardial infarction, stroke, obesity, type II diabetes, gout and tumors without detailed specification (table 3).

The prevalence of renal disease tended to be lower in AA or GA carriers than in GG carriers, a difference statistically significant only for female GA\&AA carriers. Individuals carrying AA had significantly more frequent transitoric ischemic attacks (TIA) than GG carriers, a difference again significant for the female population (table 3).

The prevalence of allergy was significantly lower in GA or GA\&AA carriers than in GG carriers, a difference significant again for the female GA\&AA population. Moreover, in contrast to the other genotypes, none of the AA carriers suffered from peptic ulcers. The difference to the prevalence of peptic ulcers in GG carriers was statistically significant. The prevalence of urolithiasis was lower in AA carriers and GA carriers than in GG carriers, a difference reaching statistical significance for the male GA or male GA\&AA population (table 3). 


\section{Kidney Blood Pressure Research}

Table 3. Association between selected diseases in oldest olds and the VDR rs2228570 polymorphism

\begin{tabular}{|c|c|c|c|c|c|c|c|c|}
\hline \multirow{2}{*}{$\begin{array}{l}\text { Genotype } \\
\text { (VDR_rs2228570) }\end{array}$} & \multicolumn{2}{|c|}{ GG } & \multicolumn{2}{|c|}{ AA } & \multicolumn{2}{|c|}{ GA \& AA } & \multicolumn{2}{|c|}{ GA } \\
\hline & $\mathrm{n}$ & $\%$ & $\mathrm{n}$ & $\%$ & $\mathrm{n}$ & $\%$ & $\mathrm{n}$ & $\%$ \\
\hline Renal disease & 10 & 27.8 & 2 & 15.4 & 10 & 15.4 & 8 & 15.4 \\
\hline 우 & 6 & 23.1 & 0 & 0 & 3 & 8.1* & 3 & 10.7 \\
\hline$\hat{\sigma}$ & 4 & 40.0 & 2 & 50.0 & 7 & 25.0 & 5 & 20.8 \\
\hline Hypertension & 22 & 61.1 & 7 & 53.9 & 31 & 47.7 & 24 & 46.2 \\
\hline 우 & 16 & 61.5 & 5 & 55.6 & 19 & 51.4 & 14 & 50.0 \\
\hline$\delta$ & 6 & 60.0 & 2 & 50.0 & 12 & 42.9 & 10 & 41.7 \\
\hline Myocardial infarction & 3 & 8.3 & 1 & 7.7 & 5 & 7.7 & 4 & 7.7 \\
\hline 우 & 2 & 7.7 & 0 & 0 & 1 & 2.7 & 1 & 3.6 \\
\hline$\delta$ & 1 & 10.0 & 1 & 25.0 & 4 & 14.3 & 3 & 12.5 \\
\hline Stroke & 2 & 5.6 & 2 & 15.4 & 7 & 10.8 & 5 & 9.6 \\
\hline 우 & 1 & 3.9 & 0 & 0 & 1 & 2.7 & 1 & 3.6 \\
\hline$\hat{\sigma}$ & 1 & 10.0 & 2 & 50.0 & 6 & 21.4 & 4 & 16.7 \\
\hline TIA & 1 & 2.8 & 3 & 23.1* & 8 & 12.3 & 5 & 9.6 \\
\hline 우 & 1 & 3.9 & 3 & $33.3^{* *}$ & 6 & 16.2 & 3 & 10.7 \\
\hline$\delta$ & 0 & 0 & 0 & 0 & 2 & 7.1 & 2 & 8.3 \\
\hline Type II Diabetes & 4 & 11.1 & 2 & 15.4 & 8 & 12.3 & 6 & 11.5 \\
\hline q & 3 & 11.5 & 0 & 0 & 2 & 5.4 & 2 & 7.1 \\
\hline$\hat{\sigma}$ & 1 & 10.0 & 2 & $50.0^{*}$ & 6 & 21.4 & 4 & 16.7 \\
\hline Obesity & 4 & 11.1 & 1 & 7.7 & 8 & 12.3 & 7 & 13.5 \\
\hline 우 & 2 & 7.7 & 0 & 0 & 3 & 8.1 & 3 & 10.7 \\
\hline$\hat{\sigma}$ & 2 & 20.0 & 1 & 25.0 & 5 & 17.9 & 4 & 16.7 \\
\hline Allergy & 12 & 33.3 & 2 & 15.4 & 10 & $15.4^{*}$ & 8 & $15.4^{*}$ \\
\hline 우 & 10 & 38.5 & 1 & 11.1 & 5 & $13.5^{*}$ & 4 & 14.3 \\
\hline$\delta$ & 2 & 20.0 & 1 & 25.0 & 5 & 17.9 & 4 & 16.7 \\
\hline Peptic Ulcer & 7 & 19.4 & 0 & $0^{*}$ & 12 & 18.5 & 12 & 23.1 \\
\hline 우 & 2 & 7.7 & 0 & 0 & 3 & 8.1 & 3 & 10.7 \\
\hline$\delta$ & 5 & 50.0 & 0 & $0^{*}$ & 9 & 32.1 & 9 & 37.5 \\
\hline Urolithiasis & 6 & 16.7 & 0 & 0 & 5 & 7.7 & 5 & 9.6 \\
\hline 우 & 2 & 7.7 & 0 & 0 & 2 & 5.4 & 2 & 7.1 \\
\hline$\hat{\sigma}$ & 4 & 40.0 & 0 & 0 & 3 & $10.7^{*}$ & 3 & $12.5^{*}$ \\
\hline Gout & 3 & 8.3 & 2 & 15.4 & 6 & 9.2 & 4 & 7.7 \\
\hline 우 & 0 & 0 & 0 & 0 & 0 & 0 & 0 & 0 \\
\hline$\hat{\sigma}$ & 3 & 30.0 & 2 & 50.0 & 6 & 21.4 & 4 & 16.7 \\
\hline Tumors (not specified) & 13 & 36.1 & 5 & 38.5 & 25 & 38.5 & 20 & 38.5 \\
\hline 우 & 9 & 34.6 & 4 & 44.4 & 9 & 24.3 & 5 & 17.9 \\
\hline 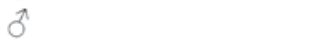 & 4 & 40.0 & 1 & 25.0 & 16 & 57.1 & 15 & 62.5 \\
\hline Depression & 8 & 22.2 & 1 & 7.7 & 4 & $6.2^{* *}$ & 3 & $5.8^{*}$ \\
\hline 우 & 4 & 15.4 & 0 & 0 & 1 & $2.7^{*}$ & 1 & 3.6 \\
\hline 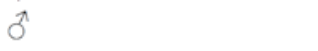 & 4 & 40.0 & 1 & 25.0 & 3 & $10.7 *$ & 2 & 8.3* \\
\hline Osteoporosis & 1 & 2.8 & 2 & 15.4 & 8 & 12.3 & 6 & 11.5 \\
\hline 우 & 1 & 3.9 & 1 & 1.1 & 4 & 10.8 & 3 & 10.7 \\
\hline 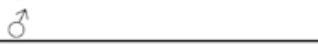 & 0 & 0 & 1 & 25.0 & 4 & 14.3 & 3 & 12.5 \\
\hline
\end{tabular}

${ }^{*}(\mathrm{p}<0.05),{ }^{* *}(\mathrm{p}<0.01)$ indicates significantly different from GG. (TIA=Transitoric Ischemic attack; $(\#)=$ positive given number)

The prevalence of depression was markedly lower in AA and GA carriers than in GG carriers, a difference reaching statistical significance for the GA\&AA population of either gender, for $q \&{ }^{\lambda} \mathrm{GA}$ carriers and for male GA carriers. As a matter of fact as many as $40 \%$ of the male GG carriers and $15 \%$ of the female GG carriers suffered from depression. The prevalence of depression was less than $10 \%$ in the GA or the GA\&AA population. To 


\section{Kidney \\ Blood Pressure Research}

Table 4. Association between measured variables in subjects $<90$ years and the VDR rs2228570 polymorphism

\begin{tabular}{|c|c|c|c|c|}
\hline $\begin{array}{l}\text { Genotype } \\
\text { (VDR_rs2228570) }\end{array}$ & GG & AA & GA \& AA & GA \\
\hline Number & $75\left(35+, 40{ }^{\star 1}\right)$ & $31(11+, 20 \AA)$ & $133\left(50+, 83{ }^{\lambda}\right)$ & $102(39+, 63 \overbrace{}^{\star})$ \\
\hline Age & $48.09 \pm 1.80$ & $49.16 \pm 2.73$ & $49.65 \pm 1.16$ & $49.79 \pm 1.27$ \\
\hline 우 & $46.03 \pm 2.65$ & $44.55 \pm 4.11$ & $46.78 \pm 1.79$ & $47.41 \pm 2.00$ \\
\hline$\hat{\sigma}$ & $49.90 \pm 2.46$ & $51.70 \pm 3.51$ & $51.37 \pm 1.49$ & $51.27 \pm 1.63$ \\
\hline Size & $172.81 \pm 0.95$ & $171.77 \pm 1.59$ & $173.33 \pm 0.77$ & $173.81 \pm 0.89$ \\
\hline 우 & $166.77 \pm 0.99$ & $168.09 \pm 2.81$ & $166.00 \pm 0.95$ & $165.41 \pm 0.94$ \\
\hline$\delta$ & $178.10 \pm 0.95$ & $173.80 \pm 1.81 *$ & $177.80 \pm 0.76$ & $179.10 \pm 0.75$ \\
\hline Weight & $72.64 \pm 1.45$ & $72.94 \pm 1.98$ & $75.44 \pm 1.12$ & $76.21 \pm 1.33$ \\
\hline 우 & $65.49 \pm 1.94$ & $65.45 \pm 1.86$ & $66.92 \pm 1.55$ & $67.33 \pm 1.92$ \\
\hline$\sigma^{2}$ & $78.90 \pm 1.56$ & $77.05 \pm 2.47$ & $80.63 \pm 1.23$ & $81.79 \pm 1.39$ \\
\hline systolic blood pressure & $134.53 \pm 2.30$ & $138.10 \pm 3.81$ & $134.85 \pm 1.84$ & $133.78 \pm 2.09$ \\
\hline 우 & $132.00 \pm 3.33$ & $131.18 \pm 7.69$ & $127.17 \pm 3.03$ & $125.91 \pm 3.21$ \\
\hline$\sigma^{2}$ & $137.22 \pm 3.14$ & $142.11 \pm 3.94$ & $139.56 \pm 2.15$ & $138.70 \pm 2.55$ \\
\hline diastolic blood pressure & $86.48 \pm 1.80$ & $85.73 \pm 2.06$ & $84.55 \pm 0.93$ & $84.16 \pm 1.04$ \\
\hline 우 & $86.91 \pm 2.91$ & $82.36 \pm 3.13$ & $81.46 \pm 1.54$ & $81.17 \pm 1.79$ \\
\hline$\sigma^{2}$ & $86.03 \pm 2.11$ & $87.68 \pm 2.66$ & $86.45 \pm 1.13$ & $86.04 \pm 1.23$ \\
\hline Blood pressure amplitude & $48.05 \pm 1.81$ & $52.37 \pm 2.94$ & $50.30 \pm 1.36$ & $49.62 \pm 1.53$ \\
\hline 우 & $45.09 \pm 2.09$ & $48.82 \pm 6.06$ & $45.72 \pm 2.33$ & $44.74 \pm 2.44$ \\
\hline$\delta$ & $51.19 \pm 2.92$ & $54.42 \pm 3.08$ & $53.11 \pm 1.59$ & $52.66 \pm 1.86$ \\
\hline Body mass index & $24.23 \pm 0.38$ & $24.68 \pm 0.54$ & $25.06 \pm 0.32$ & $25.17 \pm 0.38$ \\
\hline 우 & $23.45 \pm 0.58$ & $23.39 \pm 1.09$ & $24.38 \pm 0.63$ & $24.65 \pm 0.74$ \\
\hline $0^{2}$ & $24.90 \pm 0.49$ & $25.39 \pm 0.55$ & $25.47 \pm 0.33$ & $25.50 \pm 0.41$ \\
\hline NEO_FFI_N & $2.80 \pm 0.07$ & $2.52 \pm 0.14$ & $2.68 \pm 0.06$ & $2.73 \pm 0.07$ \\
\hline 우 & $2.91 \pm 0.10$ & $2.91 \pm 0.26$ & $2.92 \pm 0.11$ & $2.93 \pm 0.13$ \\
\hline$\delta$ & $2.70 \pm 0.10$ & $2.33 \pm 0.14 *$ & $2.54 \pm 0.07$ & $2.61 \pm 0.08$ \\
\hline NEO_FFI_E & $3.14 \pm 0.07$ & $3.38 \pm 0.08^{*}$ & $3.25 \pm 0.04$ & $3.21 \pm 0.05$ \\
\hline 우 & $3.19 \pm 0.09$ & $3.46 \pm 0.11$ & $3.26 \pm 0.08$ & $3.21 \pm 0.09$ \\
\hline$\delta$ & $3.09 \pm 0.10$ & $3.34 \pm 0.10$ & $3.24 \pm 0.05$ & $3.21 \pm 0.06$ \\
\hline NEO_FFI_O & $3.50 \pm 0.06$ & $3.53 \pm 0.09$ & $3.55 \pm 0.04$ & $3.56 \pm 0.05$ \\
\hline 우 & $3.55 \pm 0.08$ & $3.68 \pm 0.15$ & $3.69 \pm 0.06$ & $3.69 \pm 0.06$ \\
\hline 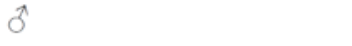 & $3.45 \pm 0.08$ & $3.46 \pm 0.11$ & $3.47 \pm 0.05$ & $3.47 \pm 0.06$ \\
\hline NEO_FFI_V & $3.62 \pm 0.05$ & $3.44 \pm 0.09$ & $3.53 \pm 0.04$ & $3.56 \pm 0.04$ \\
\hline 우 & $3.62 \pm 0.06$ & $3.56 \pm 0.13$ & $3.62 \pm 0.06$ & $3.64 \pm 0.06$ \\
\hline$\sigma^{2}$ & $3.61 \pm 0.07$ & $3.38 \pm 0.12$ & $3.48 \pm 0.05$ & $3.51 \pm 0.05$ \\
\hline NEO_FFI_G & $3.80 \pm 0.06$ & $3.90 \pm 0.09$ & $3.85 \pm 0.05$ & $3.84 \pm 0.06$ \\
\hline 우 & $3.73 \pm 0.06$ & $3.78 \pm 0.17$ & $3.80 \pm 0.08$ & $3.81 \pm 0.09$ \\
\hline 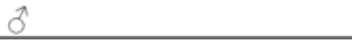 & $3.87 \pm 0.11$ & $3.97 \pm 0.11$ & $3.88 \pm 0.07$ & $3.86 \pm 0.08$ \\
\hline
\end{tabular}

further test the impact of the FokI polymorphism on mood a German version of the NEOFFI, allowing reliable and valid assessment of personality traits, was employed to evaluate the younger population. As illustrated in table 4, NEO-FFI_N score reflecting neuroticism tended to be lower in AA and GA carriers than in GG carriers, a difference reaching statistical significance for male AA carriers. Conversely, the NEO-FFI_E score reflecting extraversion was significantly higher in AA carriers than in GG carriers.

\section{Discussion}

The present observations reveal an impact of the FokI vitamin D receptor VDR (rs2228570) polymorphism in an oldest old population on instrumental activity of daily life (IADL)-score, diastolic blood pressure, (male) hospital visits, prevalence of (female) renal 
disease, allergy, peptic ulcer, (male) urolithiasis, transitoric ischemic attacks and depression. The present statistical analysis did not include Bonferroni correction and is limited by lack of a replication cohort. The observations thus allow suggestions rather than firm conclusions. Nevertheless, several observations were made in both, female and male individuals. Moreover, the personality traits apparent from NEO-FFI in younger (age 49 years) individuals supported a role of vitamin D receptor VDR in neuroticism and extraversion.

Variants of the vitamin D receptor gene have previously been shown to be associated with the susceptibility to age-related changes in cognitive function and depressive symptoms [54]. The functional impact of VDR may mimick the functional consequences of vitamin D deficiency or excess and/or deranged formation of $1,25(\mathrm{OH})_{2} \mathrm{D}_{3}$. A VDR polymorphism with reduced function such as the FokI gene variant AA were expected to have a similar functional impact as Vitamin D deficiency, the opposite of what has been observed. In an earlier study [55], we could show an association between $1,25(\mathrm{OH})_{2} \mathrm{D}_{3}$ serum concentration and personality traits, i.e. increased $1,25(\mathrm{OH})_{2} \mathrm{D}_{3}$ concentrations were associated with higher scores in the personality dimensions of extraversion and openness. Extraversion is negatively correlated with social phobia, cluster $\mathrm{C}$ personality disorders and suicide risk, which are more prevalent in depressive patients than in the general population $[16,56]$. Along those lines, the seasonal variations of sun exposure and thus $1,25(\mathrm{OH})_{2} \mathrm{D}_{3}$ formation have been associated with seasonal affective disorders [57-59]. In animals, vitamin D deficiency leads to increased anxiety, less explorative behavior, aberrant grooming, submissive social behavior, maternal cannibalism and social neglect [60-62]. 1,25(OH) ${ }_{2} \mathrm{D}_{3}$ may in mice further lead to altered emotional/anxiety states [17]. The desynchronisation in seasonal affective disorders has thus been suggested to result from vitamin $\mathrm{D}_{3}$ deficiency [63]. Moreover, depression may be associated with decreased serum $25(\mathrm{OH}) \mathrm{D}_{3}$ levels $[64,65]$. Conversely, vitamin D supplementation may counteract depressive symptoms [57-59]. Vitamin D deficiency during development of the brain has been considered a risk factor for schizophrenia, a condition associated with higher levels of neuroticism and lower levels of extraversion [66]. Conversely high vitamin D consumption decreases the risk to develop psychoticlike symptoms [15]. Several mechanisms could contribute to the effect of $1,25(\mathrm{OH})_{2} \mathrm{D}_{3}$ on the brain, including antioxidant and anti-inflammatory defenses against vascular injury, stimulation of neurotrophins and improvement of metabolic and cardiovascular function [10]. Behavioral alterations in response to vitamin D deficiency may result from alterations in cellular development, dopamine metabolism, and brain morphology [67]. Moreover, $1,25(\mathrm{OH})_{2} \mathrm{D}_{3}$ may, at least in theory, affect neuronal function by influencing cellular $\mathrm{Ca}^{2+}$ entry and/or exit $[1,68,69]$. Earlier studies suggested a cross-talk between vitamin $\mathrm{D}_{3}$ and glucocorticoids, which in turn impact on major depression [70]. Input nuclei to the pineal gland express $1,25(\mathrm{OH})_{2} \mathrm{D}_{3}$ dependent calcium binding protein [71].

The present study does not allow safe conclusions as to the causes for the seeming contrast between the impact of the FokI VDR polymorphism observed in this study and Vitamin $\mathrm{D}$ availability or $1,25(\mathrm{OH})_{2} \mathrm{D}_{3}$ plasma levels reported earlier. It is noteworthy, however, that VDR stimulates Klotho and FGF23 expression, which in turn inhibit $1,25(\mathrm{OH})_{2} \mathrm{D}_{3}$ formation [72]. Thus, a negative feedback may be expected to blunt the functional impact of VDR polymorphisms. Moreover, the tight regulation of $1,25(\mathrm{OH})_{2} \mathrm{D}_{3}$ formation dampens the impact of dietary vitamin $\mathrm{D}$ [72]. It were even feasable that a loss of function VDR polymorphism enhances the formation of $1,25(\mathrm{OH})_{2} \mathrm{D}_{3}$ with up-regulation of VDR independent $1,25(\mathrm{OH})_{2} \mathrm{D}_{3}$ effects. Clearly, additional experimental observations are necessary to either confirm or disprove the presently observed association of the FokI VDR gene variants with mood and its relation to vitamin D supplementation and $1,25(\mathrm{OH})_{2} \mathrm{D}_{3}$ plasma concentrations.

The VDR rs2228570 polymorphism is expected to impact on further functional consequences and/or disorders. The FokI VDR polymorphism is associated with bone density [73] and is expected to impact on osteoporosis given the known effect of the VDR in mineralization of bone [23]. In the present study AA/GA carriers tended to suffer more frequently from osteoporosis, a difference, however, not reaching statistical significance. VDR rs2228570 polymorphisms have further been shown to impact on blood pressure and 


\section{Kidney Blood Pressure Research}

prevalence of hypertension [26]. Vitamin D deficiency may limit mobility in community dwelling older adults [74], which may impact on instrumental activity of daily life (IADL)score. In theory, the influence on the prevalence of peptic ulcers may be secondary to stimulation of intestinal $\mathrm{Ca}^{2+}$ absorption with subsequent increase of extracellular $\mathrm{Ca}^{2+}$ and stimulation of gastric $\mathrm{H}^{+}$secretion by the $\mathrm{Ca}^{2+}$ sensing receptor $[75,76]$. The known influence of VDR on the immune response [6-8] may have contributed to or even accounted for the impact of the VDR rs2228570 polymorphism on allergy. Previous observations revealed an influence of the FokI VDR polymorphism on prevalance and/or clinical course of asthma [27, 28], immune type 1 diabetes [77], multiple sclerosis [31], systemic lupus erythematosus [78], graft rejection [79], ulcerative colitis [40], aggressive periodontitis [30] and dengue hemorrhagic fever [80].

Our study did not show a consistent impact of VDR polymorphisms on cardiac infarction, diabetes mellitus and tumor growth. Several earlier studies similarly failed to reveal an impact of VDR polymorphisms on coronary artery disease [41] or malignancy [42-45]. Other studies, however, did show an impact of VDR polymorphisms on the prevalence of diabetes mellitus $[24,25]$, diabetic nephropathy [24] and malignancy [33-38, 45, 81]. Specifically, Fok1 VDR polymorphisms have been reported to impact on breast, prostate, skin, colorectum, ovary and bladder cancer with strongest impact on breast cancer, prostate cancer and malignant melanoma [45]. Increased blood vitamin D levels are associated with reduced occurrence of and reduced mortality from malignancy [81] and vitamin D deficiency worsens the prognosis of some cancers [82]. However, vitamin D supplementation did not improve the prognosis of prostate cancer patients [82]. Despite the impact of the VDR FokI polymorphism on several pathophysiologically relevant functions, the prevalence of the polymorphism is not significantly different beetween the young and the oldest old population or between the oldest old and the common population. In view of the limited number of individuals tested, the present study does not exclude an influence of the polymorphism on life span. Moreover, the different gender distribution in homozygote and heterozygote carriers of the FokI polymorphism may point to gender differences in the impact of the genotype on survival. Beyond that the impact of the polymorphism on health risk and survival may depend on the age of the individual. Interestingly, the polymorphism was associated with the life span of the parents (not shown). Possibly, life span before or beyond the age of the individuals studied is affected by the polymorphism.

\section{Conclusions}

Besides a potential influence of the FokI VDR polymorphism on instrumental activity of daily life (IADL)-score and diastolic blood pressure, as well as prevalence of renal disease, transitoric ischemic attacks, allergy, urolithiasis and peptic ulcer, the present observations suggest that FokI VDR polymorphism impacts on the prevalence of depression, an observation highlighting the role of $1,25(\mathrm{OH})_{2} \mathrm{D}_{3}$ in the regulation of neuronal function.

\section{Conflicts of Interest}

The authors declare that they have no potential conflict of interest.

\section{Acknowledgements}

The authors acknowledge the meticulous preparation of the manuscript by Ali Soleimanpour and Lejla Subasic. The study was supported by the Robert Bosch Foundation, Stuttgart, Germany, and the Open Access Publishing Fund of Tuebingen University. 


\section{Kidney \\ Blood Pressure Research}

\section{Kidney Blood Press Res 2013;37:311-322}

\begin{tabular}{l|l}
\hline DOI: $10.1159 / 000350159$ & (c) 2013 S. Karger AG, Basel \\
\hline
\end{tabular}

Published online: September 14, 2013

www.karger.com/kbr

\section{References}

1 Ramasamy I: Recent advances in physiological calcium homeostasis. Clin Chem Lab Med 2006;44:237-273.

2 Zehnder D, Hewison M: The renal function of 25-hydroxyvitamin D3-1alpha-hydroxylase. Mol Cell Endocrinol 1999;151:213-220.

3 Heine G, Niesner U, Chang HD, Steinmeyer A, Zugel U, Zuberbier T, Radbruch A, Worm M: 1,25-dihydroxyvitamin D(3) promotes IL-10 production in human B cells. Eur J Immunol 2008;38:22102218.

4 Hewison M, Kantorovich V, Liker HR, Van Herle AJ, Cohan P, Zehnder D, Adams JS: Vitamin D-mediated hypercalcemia in lymphoma: evidence for hormone production by tumor-adjacent macrophages. J Bone Miner Res 2003;18:579-582.

5 Hewison M, Freeman L, Hughes SV, Evans KN, Bland R, Eliopoulos AG, Kilby MD, Moss PA, Chakraverty R: Differential regulation of vitamin D receptor and its ligand in human monocyte-derived dendritic cells. J Immunol 2003;170:5382-5390.

6 Cantorna MT, Zhu Y, Froicu M, Wittke A: Vitamin D status, 1,25-dihydroxyvitamin D3, and the immune system. Am J Clin Nutr 2004;80:1717S-1720S.

7 Deluca HF, Cantorna MT: Vitamin D: its role and uses in immunology. FASEB J 2001;15:2579-2585.

-8 Haroon M, Fitzgerald 0: Vitamin D and its emerging role in immunopathology. Clin Rheumatol 2012;31:199-202.

9 Reis AF, Hauache OM, Velho G: Vitamin D endocrine system and the genetic susceptibility to diabetes, obesity and vascular disease. A review of evidence. Diabetes Metab 2005;31:318-325.

$\checkmark 10$ Cherniack EP, Troen BR, Florez HJ, Roos BA, Levis S: Some new food for thought: the role of vitamin D in the mental health of older adults. Curr Psychiatry Rep 2009;11:12-19.

11 Schaller M, Murray DR: Pathogens, personality, and culture: disease prevalence predicts worldwide variability in sociosexuality, extraversion, and openness to experience. J Pers Soc Psychol 2008;95:212-221.

-12 Deluca HF: The vitamin D story: a collaborative effort of basic science and clinical medicine. FASEB J 1988;2:224-236.

$>13$ Hutchinson MS, Grimnes G, Joakimsen RM, Figenschau Y, Jorde R: Low serum 25-hydroxyvitamin D levels are associated with increased all-cause mortality risk in a general population: the Tromso study. Eur J Endocrinol 2010;162:935-942.

14 Melamed ML, Kumar J: Low levels of 25-hydroxyvitamin D in the pediatric populations: prevalence and clinical outcomes. Ped Health 2010;4:89-97.

15 Hedelin M, Lof M, Olsson M, Lewander T, Nilsson B, Hultman CM, Weiderpass E: Dietary intake of fish, omega-3, omega- 6 polyunsaturated fatty acids and vitamin $D$ and the prevalence of psychotic-like symptoms in a cohort of 33,000 women from the general population. BMC Psychiatry 2010;10:38.

16 Jylhä P, Mantere O, Melartin T, Suominen K, Vuorilehto M, Arvilommi P, Leppämäki S, Valtonen H, Rytsälä H, Isometsä E: Differences in neuroticism and extraversion between patients with bipolar I or II and general population subjects or major depressive disorder patients. J Affect Disord 2010;125(1-3):42-52.

17 Minasyan A, Keisala T, Lou YR, Kalueff AV, Tuohimaa P: Neophobia, sensory and cognitive functions, and hedonic responses in vitamin D receptor mutant mice. J Steroid Biochem Mol Biol 2007;104:274-280.

18 Ascherio A, Munger KL, Simon KC: Vitamin D and multiple sclerosis. Lancet Neurol 2010;9:599-612.

-19 Arvold DS, Odean MJ, Dornfeld MP, Regal RR, Arvold JG, Karwoski GC, Mast DJ, Sanford PB, Sjoberg RJ: Correlation of symptoms with vitamin D deficiency and symptom response to cholecalciferol treatment: a randomized controlled trial. Endocr Pract 2009;15:203-212.

20 Wang Y, Zhu J, Deluca HF: Where is the vitamin D receptor? Arch Biochem Biophys 2012;523:123-133.

21 Adams JS, Hewison M: Extrarenal expression of the 25-hydroxyvitamin D-1-hydroxylase. Arch Biochem Biophys 2012;523:95-102.

22 Eyles DW, Smith S, Kinobe R, Hewison M, McGrath JJ: Distribution of the vitamin D receptor and 1 alphahydroxylase in human brain. J Chem Neuroanat 2005;29:21-30.

-23 Jakubowska-Pietkiewicz E, Mlynarski W, Klich I, Fendler W, Chlebna-Sokol D: Vitamin D receptor gene variability as a factor influencing bone mineral density in pediatric patients. Mol Biol Rep 2012;39:62436250. 


\section{Kidney \\ Blood Pressure Research}

Kidney Blood Press Res 2013;37:311-322

\begin{tabular}{l|l}
\hline DOI: $10.1159 / 000350159$ & $\begin{array}{l}\text { C } 2013 \text { S. Karger AG, Basel } \\
\text { www.karger.com/kbr }\end{array}$ \\
\hline Published onlIne: September 14, 2013 &
\end{tabular}

Glocke/Lang/Schaeffeler/Lang/Schwab/Lang: Impact of FokI VDR polymorphism

24 Vedralova M, Kotrbova-Kozak A, Zeleznikova V, Zoubkova H, Rychlik I, Cerna M: Polymorphisms in the Vitamin D Receptor Gene and Parathyroid Hormone Gene in the Development and Progression of Diabetes Mellitus and its Chronic Complications, Diabetic Nephropathy and Non-Diabetic Renal Disease. Kidney Blood Press Res 2012;36:1-9.

25 Bid HK, Konwar R, Aggarwal CG, Gautam S, Saxena M, Nayak VL, Banerjee M: Vitamin D receptor (FokI, BsmI and TaqI) gene polymorphisms and type 2 diabetes mellitus: a North Indian study. Indian J Med Sci 2009;63:187-194.

-26 Swapna N, Vamsi UM, Usha G, Padma T: Risk conferred by FokI polymorphism of vitamin D receptor (VDR) gene for essential hypertension. Indian J Hum Genet 2011;17:201-206.

-27 Li F, Jiang L, Willis-Owen SA, Zhang Y, Gao J: Vitamin D binding protein variants associate with asthma susceptibility in the Chinese Han population. BMC Med Genet 2011;12:103.

28 Pillai DK, Iqbal SF, Benton AS, Lerner J, Wiles A, Foerster M, Ozedirne T, Holbrook HP, Payne PW, Jr., GordishDressman H, Teach SJ, Freishtat RJ: Associations between genetic variants in vitamin D metabolism and asthma characteristics in young African Americans: a pilot study. J Investig Med 2011;59:938-946.

29 Deng H, Liu F, Pan Y, Jin X, Wang H, Cao J: BsmI, TaqI, ApaI, and FokI polymorphisms in the vitamin D receptor gene and periodontitis: a meta-analysis of 15 studies including 1338 cases and 1302 controls. J Clin Periodontol 2011;38:199-207.

30 Park KS, Nam JH, Choi J: The short vitamin D receptor is associated with increased risk for generalized aggressive periodontitis. J Clin Periodontol 2006;33:524-528.

-31 Mirzaei K, Ahmadi S, Hossein-Nezhad A, Mokhtari F: Potential role of OPG/RANKL system and FokI genotypes in pathogenesis and clinical manifestations in multiple sclerosis. Minerva Med 2012;103:313321.

-32 Cox MB, Ban M, Bowden NA, Baker A, Scott RJ, Lechner-Scott J: Potential association of vitamin D receptor polymorphism Taq1 with multiple sclerosis. Mult Scler 2012;18:16-22.

-33 Anic GM, Thompson RC, Burton NL, Olson JJ, Browning JE, Madden MH, Reed MF, Forsyth PA, Egan KM: An exploratory analysis of common genetic variants in the vitamin D pathway including genome-wide associated variants in relation to glioma risk and outcome. Cancer Causes Control 2012;23:1443-1449.

-34 Barroso E, Fernandez LP, Milne RL, Pita G, Sendagorta E, Floristan U, Feito M, Aviles JA, Martin-Gonzalez M, Arias JI, Zamora P, Blanco M, Lazaro P, Benitez J, Ribas G: Genetic analysis of the vitamin D receptor gene in two epithelial cancers: melanoma and breast cancer case-control studies. BMC Cancer 2008;8:385.

35 Anderson LN, Cotterchio M, Cole DE, Knight JA: Vitamin D-related genetic variants, interactions with vitamin D exposure, and breast cancer risk among Caucasian women in Ontario. Cancer Epidemiol Biomarkers Prev 2011;20:1708-1717.

-36 Lurie G, Wilkens LR, Thompson PJ, Carney ME, Palmieri RT, Pharoah PD, Song H, Hogdall E, Kjaer SK, DiCioccio RA, McGuire V, Whittemore AS, Gayther SA, Gentry-Maharaj A, Menon U, Ramus SJ, Goodman MT: Vitamin D receptor rs2228570 polymorphism and invasive ovarian carcinoma risk: pooled analysis in five studies within the Ovarian Cancer Association Consortium. Int J Cancer 2011;128:936-943.

-37 Jenab M, McKay J, Bueno-de-Mesquita HB, van Duijnhoven FJ, Ferrari P, Slimani N, Jansen EH, Pischon T, Rinaldi S, Tjonneland A, Olsen A, Overvad K, Boutron-Ruault MC, Clavel-Chapelon F, Engel P, Kaaks R, Linseisen J, Boeing H, Fisher E, Trichopoulou A, Dilis V, Oustoglou E, Berrino F, Vineis P, Mattiello A, Masala G, Tumino R, Vrieling A, van Gils CH, Peeters PH, Brustad M, Lund E, Chirlaque MD, Barricarte A, Suarez LR, Molina E, Dorronsoro M, Sala N, Hallmans G, Palmqvist R, Roddam A, Key TJ, Khaw KT, Bingham S, Boffetta P, Autier P, Byrnes G, Norat T, Riboli E: Vitamin D receptor and calcium sensing receptor polymorphisms and the risk of colorectal cancer in European populations. Cancer Epidemiol Biomarkers Prev 2009;18:2485-2491.

-38 McKay JD, McCullough ML, Ziegler RG, Kraft P, Saltzman BS, Riboli E, Barricarte A, Berg CD, Bergland G, Bingham S, Brustad M, Bueno-de-Mesquita HB, Burdette L, Buring J, Calle EE, Chanock SJ, Clavel-Chapelon F, Cox DG, Dossus L, Feigelson HS, Haiman CA, Hankinson SE, Hoover RN, Hunter DJ, Husing A, Kaaks R, Kolonel LN, Le Marchand L, Linseisen J, McCarty CA, Overvad K, Panico S, Purdue MP, Stram DO, Stevens VL, Trichopoulos D, Willett WC, Yuenger J, Thun MJ: Vitamin D receptor polymorphisms and breast cancer risk: results from the National Cancer Institute Breast and Prostate Cancer Cohort Consortium. Cancer Epidemiol Biomarkers Prev 2009;18:297-305. 


\section{Kidney \\ Blood Pressure Research}

Kidney Blood Press Res 2013;37:311-322

\begin{tabular}{l|l}
\hline DOI: $10.1159 / 000350159$ & (c) 2013 S. Karger AG, Basel \\
\hline
\end{tabular}

Published online: September 14, 2013

www.karger.com/kbr

Glocke/Lang/Schaeffeler/Lang/Schwab/Lang: Impact of FokI VDR polymorphism

-39 Orton SM, Ramagopalan SV, Para AE, Lincoln MR, Handunnetthi L, Chao MJ, Morahan J, Morrison KM, Sadovnick AD, Ebers GC: Vitamin D metabolic pathway genes and risk of multiple sclerosis in Canadians. J Neurol Sci 2011;305:116-120.

40 Hughes DJ, McManus R, Neary P, O'morain C, O'sullivan M: Common variation in the vitamin D receptor gene and risk of inflammatory bowel disease in an Irish case-control study. Eur J Gastroenterol Hepatol 2011;23:807-812.

41 Pan XM, Li DR, Yang L, Wang EY, Chen TY, Liu YJ, Liu M, Liao ZG: No association between vitamin D receptor polymorphisms and coronary artery disease in a Chinese population. DNA Cell Biol 2009;28:521-525.

42 Pao JB, Yang YP, Huang CN, Huang SP, Hour TC, Chang TY, Lan YH, Lu TL, Lee HZ, Juang SH, Huang CY, Bao BY: Vitamin D receptor gene variants and clinical outcomes after androgen-deprivation therapy for prostate cancer. World J Urol 2013;31:281-287.

43 Dorjgochoo T, Delahanty R, Lu W, Long J, Cai Q, Zheng Y, Gu K, Gao YT, Zheng W, Shu XO: Common genetic variants in the vitamin D pathway including genome-wide associated variants are not associated with breast cancer risk among Chinese women. Cancer Epidemiol Biomarkers Prev 2011;20:2313-2316.

44 Bentley RW, Keown DA, Gearry RB, Cameron VA, Keenan J, Roberts RL, Day AS: Vitamin D receptor polymorphisms in colorectal cancer in New Zealand: an association study. NZ Med J 2012;125:47-51.

45 Kostner K, Denzer N, Muller CS, Klein R, Tilgen W, Reichrath J: The relevance of vitamin D receptor (VDR) gene polymorphisms for cancer: a review of the literature. Anticancer Res 2009;29:3511-3536.

46 Saijo T, Ito M, Takeda E, Huq AH, Naito E, Yokota I, Sone T, Pike JW, Kuroda Y: A unique mutation in the vitamin D receptor gene in three Japanese patients with vitamin D-dependent rickets type II: utility of single-strand conformation polymorphism analysis for heterozygous carrier detection. Am J Hum Genet 1991;49:668-673.

47 Whitfield GK, Remus LS, Jurutka PW, Zitzer H, Oza AK, Hope T, Dang HTL, Haussler CA, Galligan MA, Thatcher ML, Dominguez CE, Haussler MR: Are human vitamin D receptor polymorphisms functionally significant?: In (Norman AW, Bouillon R, and Thomasset M, eds) Vitamin D Endocrine System, Structural, Biological, Genetic and Clinical Aspects. Riverside, CA, University of California, 2000, pp. 817-823.

48 Arai H, Miyamoto K, Taketani Y, Yamamoto H, Iemori Y, Morita K, Tonai T, Nishisho T, Mori S, Takeda E: A vitamin D receptor gene polymorphism in the translation initiation codon: effect on protein activity and relation to bone mineral density in Japanese women. J Bone Miner Res 1997;12:915-921.

-49 Jurutka PW, Remus LS, Whitfield GK, Thompson PD, Hsieh JC, Zitzer H, Tavakkoli P, Galligan MA, Dang HT, Haussler CA, Haussler MR: The polymorphic N terminus in human vitamin D receptor isoforms influences transcriptional activity by modulating interaction with transcription factor IIB. Mol Endocrinol 2000;14:401-420.

50 Colin EM, Weel AE, Uitterlinden AG, Buurman CJ, Birkenhager JC, Pols HA, van Leeuwen JP: Consequences of vitamin D receptor gene polymorphisms for growth inhibition of cultured human peripheral blood mononuclear cells by 1, 25-dihydroxyvitamin D3. Clin Endocrinol (Oxf) 2000;52:211-216.

-51 Frey A, Lampert A, Waldegger S, Jeck N, Waldegger P, Artunc F, Seebohm G, Lang UE, Kupka S, Pfister M, Hoppe J, Gerloff C, Schaeffeler E, Schwab M, Lang F: Influence of gain of function epithelial chloride channel ClC-Kb mutation on hearing thresholds. Hear Res 2006;214:68-75.

52 Costa PT, McCrae RR: Revised NEO personality inventory (NEO-PI-R) and NEO-five factor inventory (NEOFFI) professional manual., Psychological Assessment Resources, Odessa, FL, 1992.

53 Borkenau P, Ostendorf F: [An attempt at separating descriptive and evaluative significant components in concepts of trait description]. Arch Psychol (Frankf) 1987;139:189-207.

54 Kuningas M, Mooijaart SP, Jolles J, Slagboom PE, Westendorp RG, van Heemst D: VDR gene variants associate with cognitive function and depressive symptoms in old age. Neurobiol Aging 2009;30:466-473.

55 Ubbenhorst A, Striebich S, Lang F, Lang UE: Exploring the relationship between vitamin D and basic personality traits. Psychopharmacology (Berl) 2011;215:733-737.

56 Voracek M: Big five personality factors and suicide rates in the United States: a state-level analysis. Percept Mot Skills 2009;109:208-212.

57 Bertone-Johnson ER: Vitamin D and the occurrence of depression: causal association or circumstantial evidence? Nutr Rev 2009;67:481-492.

58 Jorde R, Sneve M, Figenschau Y, Svartberg J, Waterloo K: Effects of vitamin D supplementation on symptoms of depression in overweight and obese subjects: randomized double blind trial. J Intern Med 2008;264:599-609. 


\section{Kidney \\ Blood Pressure Research}

59 Shipowick CD, Moore CB, Corbett C, Bindler R: Vitamin D and depressive symptoms in women during the winter: a pilot study. Appl Nurs Res 2009;22:221-225.

60 Kalueff AV, Lou YR, Laaksi I, Tuohimaa P: Increased anxiety in mice lacking vitamin D receptor gene. Neuroreport 2004;15:1271-1274.

61 Kalueff AV, Lou YR, Laaksi I, Tuohimaa P: Abnormal behavioral organization of grooming in mice lacking the vitamin D receptor gene. J Neurogenet 2005;19:1-24.

62 Zou J, Minasyan A, Keisala T, Zhang Y, Wang JH, Lou YR, Kalueff A, Pyykko I, Tuohimaa P: Progressive hearing loss in mice with a mutated vitamin D receptor gene. Audiol Neurootol 2008;13:219-230.

-63 Lansdowne AT, Provost SC: Vitamin D3 enhances mood in healthy subjects during winter. Psychopharmacology (Berl) 1998;135:319-323.

64 Hoogendijk WJ, Lips P, Dik MG, Deeg DJ, Beekman AT, Penninx BW: Depression is associated with decreased 25-hydroxyvitamin D and increased parathyroid hormone levels in older adults. Arch Gen Psychiatry 2008;65:508-512.

65 Wilkins CH, Sheline YI, Roe CM, Birge SJ, Morris JC: Vitamin D deficiency is associated with low mood and worse cognitive performance in older adults. Am J Geriatr Psychiatry 2006;14:1032-1040.

66 Herran A, Sierra-Biddle D, Cuesta MJ, Sandoya M, Vazquez-Barquero JL: Can personality traits help us explain disability in chronic schizophrenia? Psychiatry Clin Neurosci 2006;60:538-545.

67 Kesby JP, Cui X, O'Loan J, McGrath JJ, Burne TH, Eyles DW: Developmental vitamin D deficiency alters dopamine-mediated behaviors and dopamine transporter function in adult female rats. Psychopharmacology (Berl) 2010;208:159-168.

68 Shumilina E, Xuan NT, Matzner N, Bhandaru M, Zemtsova IM, Lang F: Regulation of calcium signaling in dendritic cells by 1,25-dihydroxyvitamin D3. FASEB J 2010;24:1989-1996.

69 Khanal RC, Nemere I: Regulation of intestinal calcium transport. Annu Rev Nutr 2008;28:179-196.

70 Obradovic D, Gronemeyer H, Lutz B, Rein T: Cross-talk of vitamin D and glucocorticoids in hippocampal cells. J Neurochem 2006;96:500-509.

-71 Celio MR, Baier W, Scharer L, Gregersen HJ, de Viragh PA, Norman AW: Monoclonal antibodies directed against the calcium binding protein Calbindin D-28k. Cell Calcium 1990;11:599-602.

72 Hu MC, Shiizaki K, Kuro-o M, Moe OW: Fibroblast growth factor 23 and Klotho: physiology and pathophysiology of an endocrine network of mineral metabolism. Annu Rev Physiol 2013;75:503-533.

-73 Jakubowska-Pietkiewicz E, Mlynarski W, Klich I, Fendler W, Chlebna-Sokol D: Vitamin D receptor gene variability as a factor influencing bone mineral density in pediatric patients. Mol Biol Rep 2012;39:62436250.

74 Yeom HA, Fleury J, Keller C: Risk factors for mobility limitation in community-dwelling older adults: a social ecological perspective. Geriatr Nurs 2008;29:133-140.

75 Geibel JP: The calcium-sensing receptor. J Nephrol 2010;23:S130-S135.

76 Remy C, Kirchhoff P, Hafner P, Busque SM, Mueller MK, Geibel JP, Wagner CA: Stimulatory pathways of the Calcium-sensing receptor on acid secretion in freshly isolated human gastric glands. Cell Physiol Biochem 2007;19:33-42.

-77 Frederiksen B, Liu E, Romanos J, Steck AK, Yin X, Kroehl M, Fingerlin TE, Erlich H, Eisenbarth GS, Rewers $M$, Norris JM: Investigation of the vitamin D receptor gene (VDR) and its interaction with protein tyrosine phosphatase, non-receptor type 2 gene (PTPN2) on risk of islet autoimmunity and type 1 diabetes: the Diabetes Autoimmunity Study in the Young (DAISY). J Steroid Biochem Mol Biol 2013;133:51-57.

78 Mostowska A, Lianeri M, Wudarski M, Olesinska M, Jagodzinski PP: Vitamin D receptor gene BsmI, FokI, ApaI and TaqI polymorphisms and the risk of systemic lupus erythematosus. Mol Biol Rep 2013;40:803810.

79 Vu D, Sakharkar P, Tellez-Corrales E, Shah T, Hutchinson I, Min DI: Association of vitamin D binding protein polymorphism with long-term kidney allograft survival in Hispanic kidney transplant recipients. Mol Biol Rep 2013;40:933-939.

-80 Alagarasu K, Honap T, Mulay AP, Bachal RV, Shah PS, Cecilia D: Association of vitamin D receptor gene polymorphisms with clinical outcomes of dengue virus infection. Hum Immunol 2012;73:1194-1199.

81 Vuolo L, Di Somma C, Faggiano A, Colao A: Vitamin D and cancer. Front Endocrinol (Lausanne) 2012;3:58.

82 Buttigliero C, Monagheddu C, Petroni P, Saini A, Dogliotti L, Ciccone G, Berruti A: Prognostic role of vitamin D status and efficacy of vitamin D supplementation in cancer patients: a systematic review. Oncologist 2011;16:1215-1227. 